\title{
WILLIAM SALTER'S LETTERS TO MARY ANN MACKINTIRE 1845-1846
}

\author{
Edited By Philip D. JoRdan
}

[Concluded]

\author{
My dear Mary: \\ Maquoketa, Iowa. March \\ $21,1846$. \\ I arrived home on the 19th . . . . I found the stage at Davenport
} full of passengers, so $\mathrm{Br}$. Adams loaned me his horse and borrowed a sulky for me, and on Wednesday I eame to Dewitt where I passed a pleasant night with $\mathrm{Br}$. Emerson. Thursday morning I got five miles on my way and met the stage with $\mathrm{Br}$. Turner and wife in on their way to his father's near Alton, Ill., so I turned back, took dinner with them at Dewitt, had a pleasant ehat . . . and came on home. . . . . I have pretty nearly made up my mind that the Lord will have me labor in his cause at Burlington and shall probably write the Church accepting their invitation next week. I design removing there then, if the Lord will, the 6th and 7th of April, but how much have I to do by way of preparation. My people have here generally expressed a strong desire that I should remain with them. I believe the Lord has given me a place -and some affectionate hearts here and it grieves me to think of leaving them. With them $I$ have labored and prayed. Here $I$ have toiled and suffered. I have reason to think that I have the confidence of the people in a large and rapidly growing section of the country, and that in time I can do them great good. Here is my pleasant study, and as fair prospect of a comfortable and quiet home. Were in these circumstances, the change a thing of my own seeking, I should distrust [it]. Although my labors here have given me a promise of accomplishing much in the future, yet I trust they may be of service to me in Burlington, although my efforts there must be in many respects of a different character. At any rate, as Br. Emerson remarked, I shall be able to sympathize with my brethren in the country.

Before I leave I am anxious to visit a good many of my people. I must prepare a farewell sermon. I have a good deal of business with one man and another to settle up, property to dispose of ete.

Burlington is a hard place, but I beg you not to think too bad of it. Don't for a moment imagine that we shall be martyrs in going there. As to worldly comforts, society, and this life we shall be more comfortably situated than we could be anywhere in the territory, unless Dubuque be excepted. If we can get the House of Worship finished this summer, 
I shan't want a better place to preach in. There are many kind and honest-hearted people, and if I can only get hold of those who ought to be under orthodox influence, I may do great good. There is a large community to work on, and though the present place of worship is full (holding about one hundred) yet when we get the church up, I shall have to gather in a congregation to fill it. A great deal depends upon a man's personal aside from his ministerial influence. People distinguish between a black coat and a fine man. My position will be a trying one. .....

Yours, Wm. Salter.

My dear Mary :

Maquoketa. Iowa. Mareh 25, 1846.

I have now decided one of the most eventful questions of my life and accepted the invitation to become pastor of the church in Burling. ton. I have endeavored this day to draw nigh to God and especially humbling myself in view of my unworthiness and unfaithfulness as a minister of Christ and imploring the divine direction [in facing] the new trying scenes before me. We have acknowledged God, thou precious friend, in this as in all our ways, and I cannot but think that this counsel is of Him, and yet I go forward in weakness and fear and in much trembling. The union of the Church and Society, the advice of many friends, the congeniality of society in Burlington to our predilections, tastes, and habits, the wide field of usefulness, and the pressure there on my mental activity which I am conscious is developed, not self-moved but only on demand, and many little things make my duty tolerably clear to my mind. Let us then go forward, giving thanks to the Lord, and trusting in His holy name. . . . . I shall commence my labors on the second Sabbath in April, and design preaching on that day from I Corinthians $2: 2 .{ }^{50}$. .

From the fact that the church in Burlington has given me a unanimous call, you may well suppose that they are not so critical as have sometimes been represented. The people were extremely kind and attentive to Br. Hutchinson. He spoke to me of their kindness to him with deep emotion, and Mrs. Hutchinson is very much beloved and tenderly sympathized with. There is but one House of Worship in the place, that is the Methodist one, a plain brick building which will seat some 350 , and is generally filled. They talk of enlarging it. Mr. Norris, their minister, is a man of good spirit from Maine. His wife is going East this summer. There are two German congregations, one Evangelical and the other Methodist. I mistake, there is a Romish House, but they have no priest now. This influence is eomparatively small, though some leading political characters are connected with it. There is an Episcopal chureh ministered to by $\mathrm{Mr}$. Bachelor, an old Andover

50 I Corinthians $2: 2$. For I determined not to know any thing among you, save Jesus Christ and Him crucifled. 
student, and an Old School Presbyterian church of some dozen members. Their minister preaches $1 / 2$ his time, is from Kentucky, and it is said, is about leaving. This Congregational church consists of about 40 members. James G. Edwards (editor of the Hawk-Eye) and A. S. Shackford are the deacons. Mrs. Edwards was formerly a member of Dr. Wisner's church in Boston, and is a devoted Christian. . . . . I preached in Burlington from John 18:36,51 Rom. 16:8, ${ }^{52}$ Psalms 90:9,53 I Corinthians $15: 3 .,^{54}$ Gal. $2: 15-16,55$ John $6: 66-68,56$ generally with ease and to an attentive congregation. Whether they will listen with so much interest when I have ceased to be "a new thing" among them is problematical. .... I find it a greater struggle than $I$ had anticipated to break away from my relations here. Many are expressing their regret at my leaving them. Mr. Shaw offered to give me an acre of land for which he has charged me $\$ 25$ if I will stay. One man who was excommunicated from the church last spring was in to see me yesterday and said he wants me to stay. I find I have formed a strong attachment to this study and to my plans for building here. One good mother in the church says she don't think I will go yet. Another thinks I will be back in a year. Mrs. Shaw complains of the people in Burlington, and Mr. Shaw says he shall feel discouraged for if they send a smart man here, someone will call him away, and if they (i.e. the A. H. M. S.) send a fool, they don't want him. ....

Yours, Wm. Salter.

My dear Mary:

Maquoketa, April 3, 1846.

.... I had a hard struggle in breaking away from Deacon Cotton and $\mathrm{Br}$. Young this week. The old men seemed to sorrow most that they should see my face no more. I shall have people of more polish and less roughness, but no warmer, no truer hearts. It seems strange that I am breaking away from them. .... I must shave before it is all night. . . . .

Yours, Wm. Salter.

51 John $18: 36$. Jesus answered, My kingdom is not of this world: if my kingdom were of this world, then would my servants fight, that I should not be delivered to the Jews: but now is my kingdom not from hence.

52 Romans 16:8. Greet Amplias, my beloved in the Lord.

53 Psalms $90: 9$. For all our days are passed away in thy wrath : we spend our years as a tale that is told.

54 I Corinthians $15: 3$. For I delivered unto you first of all that which I also recelved, how that Christ died for our sins according to the scriptures.

55 Galatians $2: 15-16$. We who are Jews by nature, and not sinners of the Gentiles, Knowing that a man is not justifled by the works of the law, but by the faith of Jesus Christ, even we have belleved in Jesus Christ, that we might be justified by the faith of Christ, and not by the works of the law : for by the works of the law shall no flesh be justified.

56 John $6: 66-68$. From that time many of his disclples went back, and walked no more with him. Then sald Jesus unto the twelve, will ye also go away? Then Simon Peter answered him, Lord, to whom shall we go, thou hast the words of eternal life. 
My dear Mary:

Burlington, Iowa. April 11, 1846.

How strange is this thing of a new home! Time in its rapid flight has hurried me here. I am surrounded by new friends, new associations, and am to engage almost in new pursuits. I am just prospectively anchored again. I moved this morning to Mr. J. G. Edward's.57 Have unpacked my books, put the table into the middle of the room, now my first pleasure is to give you my first thoughts. Would that you were with me. .... I must tell you of my journey. Last Sabbath I had a large and deeply interested congregation at Maquoketa. $\mathrm{Br}$. Young and his two boys came 10 miles on foot to be present. In the afternoon, I preached my farewell, and administered the sacrament. An interesting young lady was received into the chureh from the Methodist church in New York. As I briefly reviewed my ministry and pointed to the graveyard where but two years ago we had buried the first corpse and where we were now almost a congregation of the dead, there was hardly a dry eye in the house. It was hard to leave so many good friends. They accepted the idea that I would come back [to] live with them in a few years. Monday of this week was a very stormy day. Tuesday it blew a tempest. Wednesday afternoon I came to De Witt and passed a very pleasant night with $\mathrm{Br}$. Emerson. The next day I came to Davenport. I found the Wopsipinicon was rising, and fording it the water came into our wagon box. I just had time to get dimner with $\mathrm{Br}$. Adams, call on a few friends, and visit the ground for the location of the projected college when a steamboat (the Falcon) came in sight. The next morning at $90^{\prime}$ 'clock, I reached Burlington. I do not board with Mr. Starr's family, as I had anticipated, in consequence of their intending to take Mrs. Hutchinson with them as soon as she can be moved, as they are also contemplating a visit East this summer. Mrs. H. has been quite sick since $I$ was here and is not now able to leave her room, though some better. Ah, the severity of her lot! How dark the ways of Providence! She has my tenderest sympathies. Anything I can do for her shall not be wanting. Mr. and Mrs. Edwards were Boston folks, they are very kind. I have a pleasant room in a one-story house. From my windows is a view of the Mississippi. In one corner are my books on some rickety shelves. In another, my bed-on the east side a Franklin stove (it is quite cold today). The family is rather large, and I shall not be so retired as I could wish. But if you ean form any idea of my situation, you may think of it as tolerably pleasant. . . . . The streets are very muddy at present. Burlington is very different from

- Maquoketa, but hardly more so than it is from Charlestown. There is everything to be done here. Some one remarked yesterday that the ehurch never had a minister who was here through the summer. . . . Mr. C. C. Shackford left for the East this week before I arrived, other-

57 Vid. Philip D. Jordan, "The Life and Works of James Gardiner Edwards" in The Journal of the Illinois State Historical Society, Vol. XXIII, No. 3. October, 1930. 
wise I would have desired him to call on your father. He is uncertain about his returning. It is rather to be hoped for that you can keep him East. He has property here, a steam flouring mill. My Church have not procured a better room for meeting, and we may have to suffer for the want until the church is built. Our singing is very poor, not much better than we had at Maquoketa.

.... My study hours are in the morning and evening. The mornings for research or planning, the evening for writing and light reading. I can make very good resolutions in entering upon my labors here. I know what it will be for me to attend to this people, but in this country we have so much outdoor work for the whole country which can only be done at sacrifice of much time, that I dare not prophesy how I shall manage. You will find out that my study is par excellence my home. I cannot tell whether I shall succeed in my studies and in preaching, but one thing I know, that I can never succeed in anything else. I would be sorry to make my own feelings and habits a criterion by which to judge others, for these are divinations of gifts, but I cannot see how anyone can succeed in the ministry unless he gives himself "wholly" to the work. It would be wicked to deny having at times some hankering after a pleasant settlement in the East, but to try to suppress those desires which, like the fool's eyes, are to the ends of the earth. I shall never lack anything of the kind. As I came down the river and meditated upon the elements of future greatness in this valley,my spirit was stirred within me to do something to make this a goodly commonwealth, which should belong to the Kingdom of Christ and be to His praise. But our destiny is sealed. We are but the East over again unless indeed there is a determination. I realize more deeply than ever the vast importance of influential men in the East. Our law in the West comes forth from your Zion. At present, however, if you are agreed, Burlington shall be enough for the measure of our ambition. And in this uncertain world we will not presume upon tomorrow. ....

Your, Wm. Salter.

My dear Mary:

Burlington, Iowa. April 22, 1846.

How do you do this pleasant aftemoon? As I look out over the river and see the fresh green of young life on shrub and tree on its banks, I want you here to respond as I call it beautiful. ..... Our congregation was crowded last Sabbath morning. I am preparing for next Sunday on the necessity of Revelation from Job $37: 23,58$ and in the afternoon wish to preach on the church as an hour of prayer for all nations. In my morning sermon I design, with some implications, to go through a systematic presentation of divine truth. My afternoon

58 Job $37: 23$. Touching the Almighty, we cannot flnd him out: he is excellent in power, and in judgment, and in plenty of justice, he will not
affict. 
sermon will be occasional and pro tempore. Thursday evening the regular weekly prayer meeting held at private homes. Friday evening of this week we design making an effort to advance the Sabbath School cause, and have a meeting appointed for that purpose. The attendance of our school is generally 60 . We want more teachers and a new library. There is also a school in a destitute part of the town called "Lower Town," superintended by one of my congregation which is in pressing want of a library. I think it deserves a donation. And if your sewing circle has not dispursed [sie] all their charities yet, would be happy if they would send on a library. The singing in my church continues very poor. The ladies have a sewing circle to aid in building the church. They think of furnishing it. They meet every fortnight. . . . .

Burlington has about 3000 inhabitants. The land rises from the river gradually. The fifth street from the river on the north part of town is on the bluff some 120 feet or more above the level of the river. HawkEye creek a spring, runs a very little bubbling stream, through the north part of town, below which is the lower town built on a more level ground. I am sorry I can't give you a draft. There are many large brick stores and some good houses with many very poor ones. A few families live in good style as people do with you, but most are poor. I don't know any town in the East like B. New Branch on the Hudson which is more than twice as large looks a little like it. . . . Mrs. Hutchinson's [health] is much better, was moved to Mr. Starr's last week. She is a woman of great fortitude. I generally call on her every day. . . . .

Wm. Salter.

My dear Mary:

[Burlington, Iowa] Thursday

6 p. m. April 28, 1846.

.... I had planned a ride out in the country yesterday with Mrs. Hutchinson, but bad weather kept me home and it rained all the day. We shall go the first pleasant day. She is mending very slowly. . . . . I visited eight families yesterday with Deacon Edwards. . . . .

Yours, Wm. Salter.

My dear Mary:

Burlington, Iowa. April 30, 1846.

.... Mr. Warren ${ }^{59}$ went East this morning, via St. Louis. I gave him a letter to your father. He is a member of my congregation. A very intelligent man, broke down in business East, I understand, and came here in 1844. His wife is from Granby (not Granville), went East a short time ago. He had learned Mr. Shackford's mill which burned down here is thrown out of business. He has gone East to get funds for a new mill. I hope he will succeed in raising them. He told me he meant to return immediately. Father can question him

59 Fitz Henry Warren. 
in extenso about Burlington. Mr. Starr talks of going East in two weeks. You ask about Mr. Starr's family. I suppose your questions now would apply to Mr. Edwards. They have no children, but an adopted daughter some 15 years old, besides Mrs. Prince, a sister of Mrs. Edwards [who] has two girls. There is also Mrs. E's mother, formerly from Portsmouth, N. H. Mr. E. has four printer boys apprentices. The house is small. Mine is a very good room. My bed is in the northeast corner. I have a bedfellow occasionally. Now Mr. Reipe, a German minister from the neighborhood of St. Louis where he is an agent of the Tract Society, is stopping with me. Several years ago, he had a German congregation here. Is a very amiable man. . . . I I really do not know what street this house is on. It is, however, the next one north of Columbia. The house is in the west end of the lot at the corner on Main street (which as you correctly say is parallel with Water street, the second street from the river). Mr. Starr lives on Fourth street, i.e. the fourth street from the river. On the same street the new church is building, one lot from the corner of Jefferson on the west side of the street. . . . Mr. Shackford thinks you were very successful in studying the geography of Burlington in the HawkEye.

Ever yours, Wm. Salter

My own dear Mary:

Burlington, Iowa. May 5, 1846.

.... I preached my sermon on Christ and Fim Crucified three times, viz., at Andrew, Burlington, and Maquoketa. Ain't I a Yankee? Adapting it, as was easily done, to different circumstances. I study and write in the forenoon. In the p. $\mathrm{m}$. I want to chat and have some music and walk with you. The sewing circle meets here (at Mrs. Edwards) this afternoon. They desire furnishing the ehurch. They meet once a fortnight. Mrs. Hutchinson is president. They have some 60 dollars in the treasury. Perhaps I shall be commissioned to buy carpets and lamps for them, and I will commission you. .... I united with this church last week. It has now 42 members. I preached a preparatory lecture on Friday extemporaneous on "Christ. and Passover." We had [a] full house on [the] Sabbath and an interesting day. A member of this church was led into daneing on a steamboat excursion this spring and it has made a good deal of talk. I called on her last Saturday. She professed penitence, and I hope that may be the end of it. But isn't that unpleasant work for a minister?.... Jacksonville ${ }^{60}$ is 100 miles from here. Mr. Edwards talks of going there to commencement the last of June, but I will wait until we can go together. . . . I I expect to see Mr. Keith at Farmington next week at the annual meeting of the Denmark Association, with which the church is now connected. Mr. Shackford talks of going out with me as dele-

60 Jacksonville, Illinois, where Jacksonville College is located. 
gate from this church. There are many, or rather a few good houses here, but none built for a minister. . . . .

Shall probably soon ascertain if $\mathrm{I}$ can rent Mr. Parson's ${ }^{61}$ [house]. A man offered me a house on Fourth street this week for $\$ 2000$. It is an eligible situation, a new house, yet not finished, and not in all respects in the best taste, but has some good things about it. . . . . I want to ride out to $\mathrm{Mr}$. Leonard ' $\mathrm{s}^{62}$ this $\mathrm{p} . \mathrm{m}$. He was formerly in the ministry in Ohio. Is an excellent man, one of the best in my church, lives three miles out of town, nearly all his family (two sons and their wives) are members of the church. ....

\section{To Mary Mackintire} from $\mathrm{Wm}$. Salter

Shall August be the month, MA.

To furnish us the happy day,

To give our hearts and hands away, in marriage bonds. I pray you say?

[Wm. Salter]

\section{My dear Mary:}

Burlington, Iowa. May 11, 1846.

.... After a great deal of rain we have some fine weather at last. Yesterday was beautiful. I had full houses both parts of the day. Our afternoon service is hereafter at 2 o'elock in order to accommodate a few families in the country. But going to meeting here is very different than it is with you. Our house is a gloomy structure and in the immediate vicinity of the steamboat landing. It would seem as though the boats conspired to annoy us, for yesterday, the thing happens not infrequently, several boats stopped there while we were engaged in public worship. One of the boats had a band which played at the time a very lively air. We were exceedingly annoyed in this way during the com. munion service Sabbath before last. As to my studies, I prepared two sermons last week. I know this is too much for me to write to advantage every week and as I have a few old sermons, I can occasionally spare myself. I generally aim to prepare a good sermon. I mean to keep in some kind of a courso of subjects. Now I have commenced with the existence of God, have preached on one of his attributes and on the necessity of Revelation. Shall have several sermons on the attributes and on the evidence of Revelation. I wish to devote most of the week to a sermon, and on Saturday to get off a kind of extemporaneous effusion. .... I often find that a hastily written sermon is often more acceptable than a labored one. I believe it was so yesterday.

Mrs. Hutchinson's health which was very poor last week is now much

61 A Burlington merchant.

62 Abner Lconard, with his two sons, David and Isaac, llved on a farm three miles west of Burlington. Although Father Leonard (the term "father" Indicating only age) assisted in meeting the Burlington church debt, be, as time went on, sought to dictate church policles, and annoyed Mr. Salter by his criticlsms of the pastor's preaching and even his style of clothing. 
improved. We moved her on Wednesday to Mr. Edwards', and as I am going to the Association today, she occupies my room this week. I rode out with her this morning. I took her to the cemetery where her husband is buried. It was an affecting hour. The Lord prepare us; my dear friend, to die. That will soon be to us a reality. Soon we shall enter upon the glories of eternity and experience what Paul and John and all departed saints have long enjoyed. ....

I am expecting Mr. Shackford here soon who will go with me as a delegate to the Association. We shall go as far as Denmark tonight. .... The weather is very pleasant and warm today, and I am expecting a fine ride. ....

Wm. Salter.

My own dear Mary:

Burlington, Iowa. May 15, 1846.

How to do this chilly east winds It has been cold enough this morning to sit by a fire, but I have been too lazy to make one. I have projected four sermons on the genuineness [of] inspiration and of the Bible, which I suppose with a sermon on war and one on Home Missions will engage my morning services on the Sabbath until my vacation. I had a pleasant journey and meeting of brethren at Farmington last week. The road, however, was in some places very muddy. The country is charming, consisting of beautiful prairies and pleasant groves. $\mathrm{Br}$. Keith was present. He has left Missouri. He found the door closed in that state against the Gospel as a system of deliverance to him that hath no helper. I trust the attention of Eastern Christians will be turned to the propriety of sending ministers when the law that tolerates them (and I speak of the law of the churches) is a studied and absolute silence on the system of southern slavery. Would it not be well, would it not probably in the issue further the cause of liberty [and] religion if the slave states and slave-holding churches were given to understand that the Gospel cannot be let down, at least at the expense of the A. H. M. S. in accommodations to their prejudices and sins. .... I have just returned from a short ride with Mrs. Hutchinson upon the river road under the bluff. The country is beautiful in the flush of early life. It is a melancholy-gratification to ride with Mrs. H. It does her a great deal of good, but she is so sad and she is not disposed to engage the sympathies of others. You ask of her character. She is dignified, reserved rather than communicative. . . . She is young, but little over 22, but has a very active appearance and mind. Her health is very much better. She now thinks she will go East in the fall. Expects to go to the Association at Dubuque. I preached my old sermon at Farmington on $I$ Cor. $2: 2,63$ telling ministers what they ought to preach. Don't you think I am a Yankee and a labor-saving man It

63 I Corinthians $2: 2$. For I determined not to know any thing among you, save Jesus Christ and Him crucifled. 
rained on Wednesday night and Thursday morning at Farmington, so that the roads were muddy coming home Saturday. I wrote a sermon on "The Christian Life, a Warfare" from I Tim. $6: 12,{ }^{\text {,4 }}$ being my 41st. written sermon. The sewing eircle are in the other room this evening and chatting at a pretty good rate. Some of them asked me if I came in from riding? If I had been to Boston? They joke me occasionally. I have written a letter to your father introducing Mr. Starr, who leaves on the next boat. It is uncertain when he will go to Boston, probably not till July. He is one of the best men here, and a very interesting man. I have charged him to call and see you. I hope he will get a few hundred dollars for the chureh. He and Dr. Ransom are of the leading men in my congregation,.... [who] ... have undertaken to build the church. They have their pay in subscriptions and from sale of pews. The doctor's wife is a member of the church and an excellent woman. . . . . I hope Dr. Ransom will call and see me. My pulpit will probably only be partially supplied during my absence, and that by different brethren here, some of whom have engaged to give me one Sabbath. ....

There will probably be a preparatory school at Davenport in a year or two. The Brethren generally have concluded that to be the best location, and the stakes are to be put down, it is supposed, next month. It is a beautiful place, and our college will be the only one of the kind on the Mississippi. The only objection to the location is its proximity to Galesburg. I have not yet extemporized but once on the Sabbath when I did not make much of a go off, and probably shall not try it again at present. Mr. Starr, Mr. Shackford, Mr. Edwards are my main dependents here. Whether $I$ can write a good sermon about the West remains to be seen. I shall try. I shall aim to show that the West will be just what others make it, and that they which will work the hardest and do most for it shall have it. Prayers and pains will save the West and the country is worth both. I don't want to ly [lie] if I can help it. . . . Burlington is a rising ground, but a great deal of low land on the other side of the river and above and below, as is everywhere the case on the Mississippi. Some call it healthy and some sickly. ....

Yours ever, Wm. Salter.

Burlington, [Iowa] Monday morning, May 25, 1846.

My dearest Mary :

.... It really at last feels like summer, and I long to be away. .... We had the news this morning of a battle between Gen. Taylor and the Mexicans on the 8th. I want to preach on the evils of war next Sabbath. I suppose there will be an end to trade from New Orleans,

64 I Timothy $6: 12$. Fight the good fight of faith, lay hold on eternal life, whereunto thou art also called and hast professed a good profession before many witnesses. 
so we may have some difficulty in getting our freight around. I had hoped I should never be in a country engaged in a war. Alas, for the prospects of humanity! ....

May 26.

And now we have another day warm and pleasant. We, Mr. Leonard [and] I, visited Rev. Abner Leonard whose name you see in the Congregational Almanac. He is an old man and has given up preaching. He is a good man, has a fine farm [now, 1934, the Deem's farm on the Agency Road], is a member of my church, was from Ohio. His son lives round him. We had a few strawberries by way of variety. They grow wild and were improved by cultivation. Mrs. Hutehinson does not gain her strength as fast as we could wish. ..... We hoped to ride out to the grave of $\mathrm{Mr}$. H. this afternoon. Instead of preaching on the evil of war, I shall discourse, I believe, on the blessing of peace from I Kings $5: 6,{ }^{65}$ as there is too much of a war spirit here, as in the West generally. I may avoid perhaps giving offense [and] secure the same object by telling what a good thing peace is. .... The rooms in Mr. Parson's house which we shall probably rent are very small. There is unfortunately a cellar kitchen from which there is a dumb-waiter to the room which must be our parlor and dining room, though I don't know but what we can make our kitchen the dining room. .... I don't know as I told you that my nerves or rather my limbs failed to sustain me a few Sabbaths ago in visiting a sick and dying woman after service. She was in a very close and small room, through which was no circulation at all, and was very low, and in much distress. I talked a little with her, but feeling the room too close for me, I went out to take the air, and returning again, talked and prayed with her. But I stayed too long and just succeeded in bidding her good-bye and in getting out of the room when I dropped into the arms of Mr. Edwards who was with me, who got me out onto the porch where the air and a little camphor restored me. . . .

Yours entirely,

Wm. Salter.

My dear Mary :

Burlington, Iowa. June 1, 1846.

How do you this chilly day, which is more like April than June? ... Burlington is in the latitude of New York. The summers are probably some warmer than with you. We had green peas last week. I called at Mr. Parson's last week, but he had gone to St. Louis. Shall call again this p.m. His house joins the end of the ehurch lot. The' Church is on Fourth street, one lot from the corner, which is unoccupied

65 I Kings $5: 6$. Now therefore command thou that they hew me cedar trees out of Lebanon: and my servants shall be with thy servants: and unto thee I will give hire for thy servants according to all that thou shalt appoint: for thou knowest that there is not among us any that can skill to hew timber like unto the Sidonians. 
and is 60 feet front by 120 feet, i. e. the lot. At the end of it is an alley some 8 feet wide and the other side of this alley is the house fronting on Jefferson street, but standing back some ways from the street. It is situated on a hillside and stands back in an angular direction, however, of a large brick house which Mr. P. is now building at a cost of some seven thousand dollars. . . . . It is in the best part of the eity. We shall be near some of the best society. Mr. Starr and Gov. Clarke, ete. I don't think we ean get any good furniture here. .... Mr. P's [house] was built two or three years ago. The rooms are small. Built in a side hill, it has a high stoop. Under it, I think, room is found for a woodshed. It has no blinds. Some of the houses have them. . . . Mrs. Hutchinson moved last week to a Mr. Hendrie's where she has a pleasant room in lower town. She is mending slowly and is expecting to go to Dubuque with us tomorrow night on the Tempest. Mr. Shackford and Mr. Edwards will go as delegates from the church here..... I had a letter from the church at Maquoketa this week. I joined up there by letter from Laight street church, New York.

.... I preached a good sermon yesterday morning on the blessings of peace, which was well received, I believe .... but as [the] Methodists had camp meeting, and it was showery, did not have a crowded house. In the afternoon preached on stability of character as essential to success in life. I hope I may be able to exemplify more and more my own doctrine. And to have a heart more entirely fixed in God.

News came today making a requisition for a regiment from Iowa for Texas. I suppose it will make some hub-bub here, but I hope the whole affair will soon pass off. What dreadful business to be fighting this 19th. century! I do believe Christians have got to take a more correct stand on the subject. I see by a St. Louis paper that one of the Presbyterian preachers there preached to a regiment. I don't see how he could preach. A great many soldiers have been good Christians, no doubt, but whether God will tolerate such things any longer, I doubt. ....

I have four Sabbaths more to preach here, my dear, before I hasten to you. I feel very anxious to secure a good hold before I leave, and though I am laboring hard, visiting a good deal, and writing two sermons a week frequently, my health continues good. I got on the scales at Shackford's last week, and found I weighed $139 \mathrm{lbs}$, which is very good weight for me. I am in hopes of a good meeting at Dubuque. The opening sermon is to be preached by Mr. Robbins. I shall expect to see $\mathrm{Br}$. Keith, and hope to be able to go down and visit my old people at Maquoketa, and spending the Sabbath with them. . . . Coming down [from Dubuque to Burlington] shall spend a day at Davenport, the 10th., at a college meeting. . . . . The commencement at Galesburg is on the 24th. If I can find time, I shall ride over there (40 miles) and spend a day.... 
Monday evening. June 1.

What a dreadful sound is this stirring drum. A meeting to enlist and fire at Patriotism tonight was held in the Methodist church. Strange place, indeed! But this is the West! . . . Took tea tonight with Mrs. Sheldon, ${ }^{6}$ an old widow lady, aged 72 . She keeps a school of very small children, some 30 or 40 in number and lives alone. She was from East Windsor, Conn., is really an interesting lady. I visited her with my deacons and had a little monthly concert. She made a great pass at the supper table for us which was loaded. Mr. Parsons wanted a little more time to consider how much rent I must pay. Our church has made no progress since Mr. Starr left. Everything looks uncertain. It is impossible to foretell the result. If the House is not enclosed by July 1 , it will be pretty much a gone case with us, but we will do the best we can .... and not be discouraged. . . .

Tuesday. $4 \frac{1}{2}$ p. in. We have been to ride with Mrs. Hutchinson, called on the doctor with her, who advises her going to Dubuque. 'I must take tea with the ladies' society this evening. ..... We have not many young ladies in our society. Hardly any. Most of the folks are young married people with small children.

Yours devotedly, Wm. Salter.

My dear Mary:

Steamer Tempest, Mississippi River near Galena, Illinois, June 4, 1846.

We are en route for Dubuque. . . . . You cannot yet be much interested in this country, and I know. not that any account of a journey would be of any concern to you, but as I have taken my pencil (there being but one inkstand on the boat, and the clerk being unable to spare that) and as nothing else especial oceurs, and I want to say a word to you .... I will tell you what I am about and perhaps it may not be an unpleasant episode from the commonplaces of the communications generally. I mailed you a letter Tuesday evening, after which I sat up till eleven 0 'clock, expecting this boat, but not coming, I went to bed and engaged in a sound sleep from which $I$ was aroused at 2 a. $\mathrm{m}$. by. loud ringing of the steamboat bell. I got up, though with some reluctance, for really sleep is a good thing and I always love to have it though when I am at it, and struck a light, and dressed and hurried to the landing where $I$ found the Tempest and learned that she would be off in some 20 minutes. So I hastened back to the house and got the folks up and down to the boat and about break of day we were on our way up stream. This disturbance at an irregular hour did not correspond very well with my staid habits. So I could eat no breakfast and soon I was troubled with the toothache and vainly longed for relief in my berth, but a erying child in the next stateroom drove

66 Mrs. Ruth Sheldon. 
sleep from my eyes, so I worried through the morning in only tolerable style. At Bloomington we took on board Mrs. Robbins and child. Her husband having gone up by land with $\mathrm{Br}$. Alden. I might have said that we have Mr. and Mrs. Edwards and their neice, Ellen Prince, a young girl of 14, and Mr. Shackford and Mrs. Hutchinson on our party. The scenery on the river is very monotonous, though with some variety. At one time we are sailing through islands, which are all very low and generally covered with a rank growth of timber and underbrush, at another time by the main shore of Iowa or Illinois, which is frequently erowned with high, rocky bluffs, 150 to 200 above the river. Sometimes the shore consists of high sand banks. About 15 miles above Bloomington commences some of the prettiest views on the Mississippi. They are on the Iowa shore, alongside of which is the channel of the river. There is a gradual slope from the river bank some 2 or 3 miles up which terminates in bluffs. This slope is frequently open prairie and is mostly under cultivation. It contains many pleasant residences. The situation of Davenport is very handsome, the projected site for our college is one of the most beautiful and commanding that could be selected. On the island of Rock Island is the beautiful residence of the late Colonel Davenport. Opposite the head of this island, on the Illinois shore, is Moline, where by damming the Mississippi a great water power has been secured. Here is one of the finest flouring mills in the West. At Rock Island, there came aboard Rev. W. Jones, of Canton, Inlinois. $\mathrm{He}$ is a product of Jacksonville College, and Lane Seminary, belongs to the Alton Presbytery and is going up to attend our Association. A young lady, Miss Shaw, is with him, who is, it is said, his particular friend. Last evening, he preached for us. The passengers gave very good attention. Audiences in the West generally are very attentive. We had pretty good singing. .... This morning we had worship. On awakening this morning, found we were laying to on the Iowa shore just above Charlestown and on inquiring the cause, learned that we had broken "the doctor" about twelve o'clock last night (it is the regulator of some part of the engine). We were till after 7 remedying that evil, and are now going direet to Dubuque. The country above the Upper Rapids is very pretty. Here the river which elsewhere spreads out, shores and all some 2 or 3 miles, passes along in a narrow channel, the banks being high on both sides. The land generally lies in handsome slopes. We have passed on our way many little towns, though towns hardly otherwise than in their names, which yet evident the ambitious views of the people. Here we have New Boston, New York, Albany, and Buffalo ete. In these Western boats the cabin is all on the upper deck in a long saloon with staterooms on the sides. I don't remember ever having been on a boat here without seeing card playing going on in one end of the saloon in the proximity of the bar. You would be anused at our Mrs. Edwards. She has brought along with her some of the purses made by our society and is selling them as she has opportunity. She is a lady of great energy and perseverence. . . . . 
Friday morning. June 5, 1846. Dubuque.

Good morning, Mary. We have still chilly weather, and I have just had a fire made up and hope to be more comfortable. We arrived here at 11 a.m. yesterday. I am pleasantly quartered in the family of $\mathrm{Mr}$. Bissel with Mr. Shackford. Mr. Bissel was from Pittsfield, Mass., and is a brother of the late Josiah Bissel, a distinguished philanthropist of western New York. . . . . Wo have a full meeting of the Association and the prospects of an interesting time. A number of brethern are over from Wisconsin. Br. Lewis is here from New Diggings. He was an old classmate in New York University. We have been delighted to meet so many old familiar faces. I could hardly contain myself as brethren, one after another, drove up yesterday afternoon..... I have the thankless office of scribe, and have my hands full. A number of my old people from Andrew and Maquoketa are here, which I am very happy to meet. ... .

[Wm. Salter]

Good evening, my dear Mary:

Steamer Fortune. June 10, 1846.

.... We had an interesting meeting at Dubuque. There was nothing special but good feeling and the presence of a good spirit. ... The cruel toothache affected me very much however. I tried various remedies in vail until .... Dr. Finley extracted it. .... At Davenport we have been spending the day in talking about locating a col- lege in Iowa. If we can carry out our projects it will be an important day, full of great results, to Iowa. May God bless our efforts to serve Him. But we have many embarrassments. Beyond a question we have one of the finest locations on the whole Mississippi. At this season of the year "you can't say anything else" of this region than that it is charming. But society in Davenport is very uncongenial to a literary institution of the character we wish to establish. And the people are very unwilling to assist in putting up a suitable building. We have settled upon Davenport as the location though with some conditions which, it is expected, will be met. The meeting is not through, but as I am anxious to be home in the morning, I left at 8 this evening. No other boat is expected down under twenty-four hours.... [The] Association adjourned to meet at Burlington the first Monday of June 1847. ....

Burlington. June 11, 1846.

Good afternoon, my dear. I got home this morning and found yours of 23 May in the office. The framing of the roof of the ehurch is nearly completed, and it is expected to be raised next week. The old School Presbyterians have their walls about half up, but I think we shall have the best house after all, as we have the best situation. . . . . I have sold most of my furniture at Maquoketa. It was of but little account. I could not have remol. $I$ it at present. If I come by the Ohio 
river, it will be still more uncertain when I reach you. Br. Lewis wants to go that way, and if the river is in a tolerable stage, $I$ shall try it, so that, after all, I don't know what to say about your writing me on the way. ..... Mrs. Ransom returned last week. She did not go any further than St. Louis..... I learned that Mr. Warren has returned from the East and that Mr. Shackford's mill is to be rebuilt. Mr. C. C. Shackford is expected here soon. I never have used a cotton mattress: I sleep now on a corn-husk mattress and find it very comfortable. .... I sit in studying and writing. I think as I was bred to books, I can probably get along in a study life with less liability to ill health than is the case with those who have commenced to study late in life and who have changed to habits of close application from those of active life.

Monday evening.

I have called to see Mr. Parsons, and find him unwilling to engage to rent his house by [the] last of September, or at any definite time. $\mathrm{He}$ is building a new house and thinks it a little improbable when he shall get into it. His new house is yet to be plastered. On these uncertainities, he will rent his house for $\$ 100$ per year. This is especially good rent, but I do not think on the whole we can do better. The kitchen is pretty much on the ground floor and alongside is a cellar. On the main floor are two rooms, one $11 \frac{1 / 2}{2}$ by 13 feet, the other $11 \frac{1}{2}$ by 15 feet and two very small bedrooms and a good pantry. There is one pretty good bedroom up [in the] garret and one very poor one and a storeroom. I think you need not worry at all about furniture till I come on. We can attend to it in a few days, and perhaps by the time I leave, we ean know eertainly whether we can have Mr. P's house, or if not he will write us at Boston. We have a prayer meeting tonight at Mrs. Sheldon's. I am preparing to preach next Sabbath on the necessity of regeneration-the Lord prepares us for usefulness and for his glory hereafter. .

Yours, Wm. Salter

Burlington, Iowa. Monday afternoon, June 22, 1846.

My own dear Mary:

.... Last Friday I went to Yellow Springs, preached twice on Saturday, and returned in the afternoon, and finished a sermon on humility which I preached yesterday afternoon. Had a pretty good congregation yesterday and hope did some good. I feel rather lazy today and have done nothing when $I$ ought to have planned out a sermon. For I am expecting to be gone three days this week, and shall be hard pushed for the next Sabbath. We had some amusing occurrences on the way to Yellow Springs which I should be glad for you to have seen and laughed over, but we may have similar ones, enough for our heart's content, one

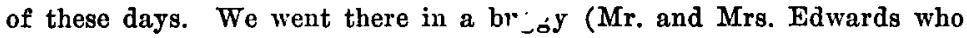


are indivisible and who make up for living in their ehildren, they haven't any, by living in one another) which was funny enough taking all things into account, and lost our road and slept in one room (Mr. and Mrs. E. behind curtains) and attended ehurch in the new meeting house without doors and with rough boards for seats and a work beneh for my pulpit. When we left on Friday it was exceptionally hot, and $I$ went in thin clothes with no overcoat, but it grew colder and colder, so that $\mathrm{Mr}, \mathrm{E}$. took a severe cold and I a slight one. . . . . The country is very beautiful now. The grain is assuming its golden hues. There will be a great wheat crop in this country. There will be plenty of blackberries, but they are not ripe yet. . . . . Since yesterday morning $I$ have had a fire in my room. You have seen the diseussion in the general assembly on slavery. ... . Two companies [for the Mexican War] have been organized in Burlington. I feel very sad in view of it. They, I hope, will not be called to. war. But it exhibits such a deplorable state of sentiments among the people that I cannot but mourn. . . . . Now, I have my fears about Mrs. Hutehinson who by the way returned here on Saturday, that she is in a decline. She has a very slight hacking cough at times, a hectic flush on her cheek, but I would not have any of her friends hear of it from me on any account. We are expecting to go together to Galesburg. She also has much pain in her side. I feel very anxious about her. Dr. Ransom is esteemed a good physician and is in many respects an interesting man. He has always been very kind to me.... We have a number of tolerably good physicians here, but I suppose none of them are first rate..... We have some first rate folks here, but not all by any means. To some extent we must be the world to one another. In so new a country, where so many other interests absorb the minds of men, the objects in which we are engaged are very much slighted. As an index for our society I may say the war is popular, and some of the leading characters are foremost in it. . . . Our ladies are making a great fuss now about getting up a dinner the 4th. of July in behalf of the ehureh. Singular to build a house by eating. Isn't this the West? But there seems no other way of raising money! Mrs. Edwards has just returned from the meeting about it, is highly elated in the prospect of getting up a good dimer. O, I do want this church built and all these trials out of the way before you come here. ....

Yours devotedly,

Wm. Salter.

Mr. A. S. Shackford is not suecessful in business. Is about breaking up. If he goes, it will be a great loss to us.

My very dear Mary:

[Burlington, Iowa] Saturday. evening, June 27, 1846.

How to do? I am very busy. Have just finished writing five letters, to which I have turned my attention from the middle of a summer, which 
I must finish today, for tomorrow afternoon, on some analogies suggested by what $I$ have seen in my travels this week, between the wheat fields and moral culture (Psalms 147:14). ${ }^{67}$ For the morning an old sermon (a. practical statement of the Trinity) must suffice. Tuesday afternoon I went to Galesburgh. Mrs. H[utchinson] was too unwell to go with me, so I took Mr. A. S. Shackford. After losing the road on the prairies we got to Galesburgh (46) miles that night and enjoyed the hospitality of a good Mr. Swift from Vermont. I learned to my sorrow that Mr. Blanchard ${ }^{68}$ was going East this summer to get funds for a college building. I engaged Rev. L. H. Parkin [?], formerly pastor at Galesburgh, to preach five Sabbaths for me. He is a brother of Dr. Joel Parkin [?], now of Philadelphia, formerly of New Orleans, and is said to be a tolerable preacher. Perhaps I will write a little notice for the Hawk-Eye next week. Coming home we got lost again and broke a piece of our harness and were two minutes too late for the ferry at Shockoquon where we were obliged to wait 18 hours amid mosquitoes and their concerts. Happily we got behind a bar at night, but the rest of the time we were much annoyed. Then I did not get home until yesterday at 11 in the morning.

Yours ardently,

Wm. Salter.

Burlington, Iowa. Monday afternoon June 29, 1846.

My own dearest Mary:

.... We had a heavy rain and wind last night, and today the streets are so muddy and $\mathrm{I}$ have not been out yet and $\mathrm{I}$ am annoyed with company. What company?, you ask. There are more than 100 flies (I have not counted them) in this room, cutting up all kinds of antics, flying in every direction, now on my ears, now on my hands, and paper, and everywhere in the way. I can do nothing but bear it. I had an interesting day yesterday, preached in the morning to a full house on the Trinity, brought it out clear and full, and trust in such a manner that no reasonable man can object. It was an old sermon, or rather written in December last. I preached thrice yesterday, in the evening in lower town in a $\log$ School House. During the service there it rained, and I came home in the mud. The ladies have been expecting to have their 4th. [of] July dimner in the Chureh, but if this wet weather continues, we camnot get the roof on or the floor laid. The whole affair involves a great deal of trouble, and $I$ cannot say that $I$ am sorry that you are not

67 Psalms $147: 14$. He maketh peace In thy borders, and flleth thee with the finest of the wheat.

68 Jonathan Blanchard (1811-1892) was graduated from Middlebury College in 1832, taught at Plattsburg Academy, studied at Andover and Lane Theological Seminary in Cincinnati. In 1838 he was ordained pastor of the Sixth Presbyterian Church there. In $\mathbf{1 8 4 5}$ he was elected president of Knox College, at Galesburg, Illinols, and in $\mathbf{1 8 6 0}$ became president of Wheaton College, Wheaton, Illinols. He was a strong temperance advocate, and a violent abolitlonist. 'Vid. Dictionary of American Biography. 
here to share in the fuss. I feel very anxious to have the church finished so that we can meet in it by the time we get back in the fall. I want the way of the Lord here made ready so that we can devote our undivided energies to building up God's spiritual House. . . . . I rode out Friday p. m. with Mrs. Hutchinson six miles to a Miss Robinson's of whom you will know more one of these days. Mrs. H. was to church yesterday. Her health is about the same, very delicate. She is a woman of strong mind, and $\mathrm{I}$ do not think has been to Mr. H's grave more than twice.....

Yours ardently, Wm. Salter.

My dear Mary:

Chicago, [Illinois] July 11, 1846.

.... [Let us begin] with that long, longed-for day, July 6 th. At length after a most solemn and seemingly never-ending delay, its sun arose. .... Monday morning, I turned my eyes down the river and looked and wished for a boat. I packed my trunk and arranged matters a little, engaged Mr. Parsons to write me in August if I could have his house, .... all the time keeping my ears open for the ringing of the steamboat bell, my eyes down stream. Two boats, it was said, were expected that day, but all day long I waited to no purpose. I might have said that Sabbath night (after twelve o'clock of course), I was awake more than half the time in hopes of hearing a boat. Monday night I slept in Mr. E's lounge in the parlor (in the expectation of my departure that day, Mr. and Mrs. E, having resumed their occupancy of my room) and kept on longing for a boat, annoyed too with mosquitoes and disturbed by a very heavy thunder storm. I found no rest. Toward morning an old boat came up and about daylight, I found the Atlas at the levee. About 8 o'clock we left Burlington. Now .... I must spare you the details of a slow boat with two keels, intense heat, mosquitoes etc., and tell you that we reached Galena at 7 Wednesday morning. I had a young lady under my care, a Miss. Whẻeler from Vermont. She has been teaching in the West and lost her health, is visiting some friends in this eity. At 80 'clock at Galena, we took the stage, via Dixon, and you cannot conceive and I will not attempt to describe our intolerable sufferings from intense heat, a loaded coach, disagreeable companions, slow traveling, and more than all arriving here last night ten minutes too late for the steamboat Champion. Had it not been for that I might have spent the Sabbath in Kalamazoo and been with you the last of next week. But now I must wait until Monday night and perhaps get no further than Albany next week. I had probably better go to New York before visiting you, so I must continue to wait and live until Wednesday, the 22 inst., to see you. I don't feel, however, much like waiting so long, and I may take the cars to Boston at Albany. . . . . Miss Wheeler's health is poor. She was rather uneasy and could not exemplify the patience of Job, but we had an interesting time together. . . . . I hope to be in Detroit in time for the London and may possibly get along 
quicker than I anticipate. . . . The Saratoga, a beautiful boat, left here for Buffalo this morning. I went down to see it off, but it only made me feel bad that I must stay here. I don't know as it is very wicked to send this off tonight. At any rate, Christian sentiment has not decided so yet, though it may be hard to tell why it is any wise different to send my letter to travel on Sunday from travelling myself on that day..... The boat leaves Sunday night at 10 'clock, if it were only two hours later I might be off.....

Yours, Wm. Salter.

Lake Erie. July 16, 1846.

My dear:

.... I find in the Edinburgh Review for April a notice of Walter Savage Landor's Collected Writings (London, 1846) which have made me.very much in love with the man. [He here quotes liberally passages concerning Milton, friendship, Bacon and Shakespeare.]

New York. Monday p. m.

Dear Mary: I got home Saturday evening in a few hours less than five days from Chicago. My heart is set on seeing you tomorrow morning, but the folks think I am too much jaded out to travel. Indeed, I have journeyed rather too hard. Perhaps I had better wait until Wednesday afternoon and come to you fresh and rested on Wednesday a. m. Should I, however, be entirely rested on tomorrow, I will come then. As to bridesmaids and all that, I shall leave it with you, as I told you sometime ago. My taste is decidedly against them. I apprehend, however, how girls have a little more fancy than we have for parade. I leave it and the time with you. I feel bad to linger on my way to you, but it seems it can't be helped. ... .

Ardently Yours, Wm. Salter.

New York. Wednesday, July 22, 1846.

Well, my dear, isn't this lingering in New York decidedly cool, but upon my honor, it ean't be helped. Sunday I was so imprudent as to go to ehurch all day, and on going to bed found myself possessed of a strange inclination to look up some blankets and after a while my fever came on. I thought, however, it was only a temporary affair, though on Monday I stirred around, but soon found I must lay by, and at night my attack came on again. I am now under our doctor's eare, who promises to break up the fever soon. Probably, then, I cannot be with you till next week, so don't have the blues, but I leave it with a wise Providence who has always ordered all things to His will. My chill is now coming on, and I would write out my sheet. I traveled in Michigan with an excellent minister, Mr. Wells of Salem. ....

Yours, Wm. Salter. 
My dear Mary:

New York. July 24, 1846.

I am certainly the last man to whom you should say "tell me the worst", for I have been doing that very thing now for a twelvemonth. I have been out all day and even presumed to ask the doctor if I might not go to Boston tomorrow, but he says, I am too weak. He suggests that to "eat and drink" will be my best way for gaining strength, rather than to take stimulants. . . . If I only had time I would [write] a prose essay on ague and fever. Suffice, however, to say, I escaped my ague yesterday and think it is broke on me. I ate dinner enough today for any hale and hearty man, so that by the middle of next week, if not on Tuesday, I think I may see you. Am glad you are so philosophical and resigned. I have not been really confined to the house in several years and this attack has many lessons for me. I hope it will serve to moderate all my earthly attachments (i. e. so far as they are earthly) and refine and elevate my spiritual being and relations. I have no doubt that it is for the best. Yes, I ought to have given more heed to your caution about not travelling so fast, but it was excessively hot and $I$ was very much [worn out] when I left Burlington. Then I ought not to have been up nearly all the evening at a crowded missionary meeting on the Sabbath here as I dir.

.... I met Mr. Magoun coming East. $\mathrm{He}$ is begging for his Academy. . . . . I am pledged to raise a bell somehow or other. I want a good, large fine sounding one. I mean such a one as I can get. ....

Yours .... Wm. Salter.

My dear Mary:

New York. July 27, 1846.

.... I have not been out since a week ago this morning, and I do not now feel as smart as I hoped I would by this time when I wrote you on Friday, and the folks won't listen to such a thing as my going east this afternoon. They say it would be the height of imprudence, and moreover, my dear, I fancy you and your friends would rather see me when I am a little less lazy than I am just now, so on the whole $I$ have concluded to wait till Wednesday, when, in addition to all, I can have the company of my Uncle Benjamin and Cousin Caroline, who are going east that day. We shall come by the Mass. via Providence. I think by that time I may be in pretty good order, but it is singular how my fever reduced my strength. Fever sores, too, have broken out on my lips. . . . . I think of going down town in the omnibus today, and tomorrow I must make a call or two, and by Wednesday, I shall be myself again, I trust. I feel very bad to think of the disarrangements this little ague may have caused you and your friends. ....

Wm. Salter. 
Copyright of Annals of Iowa is the property of State of Iowa, by \& through the State Historical Society of Iowa and its content may not be copied or emailed to multiple sites or posted to a listserv without the copyright holder's express written permission. However, users may print, download, or email articles for individual use. 